\title{
Determinan kemampuan pemeriksa dalam mendeteksi fraud
}

\author{
Puspita Wulan Dari ${ }^{1}$, Wahyudin Nor ${ }^{1}$, Rasidah $^{1}$ \\ ${ }^{1}$ Universitas Lambung Mangkurat, Jl. Brigjen H. Hasan Basry, Banjarmasin, Indonesia.
}

\author{
Diterima: \\ 18 November 2020 \\ Direvisi: \\ 18 Desember 2020, \\ 13 Januari 2021, \\ 29 Maret 2021 \\ Disetujui: \\ 20 April 2021
}

Korespondensi:

Puspita Wulan Dari

puspitawuland@gmail.com

DOI:

http://dx.doi.org/10.17977/

um004v8i22021p085

\begin{abstract}
Fraudulent behavior continues to happen, showing that the eradication of this act is difficult. Fraud has costed a lot to the economy of the country. Hence, based on the UUD 1945, the government forms The Audit Board of The Republic Indonesia (BPK RI) which is an independent body that was responsible for auditing, management and financial responsibility of the state. This research aims to investigate the effect of examination experience, red flags, audit time budget pressure, workload, and personality type with the ability to detect fraud. This study used saturated sample method or census with the population of 32 independent BPK RI examiners in East Kalimantan Province. The data was collected through an online questionnaire and analyzed by using a multiple linear regression. The results of this study indicate that the audit experience and red flags variables affect the ability to detect fraud. Meanwhile, the audit time budget pressure, professional skepticism, workload, and personality type have no effect on the ability to detect fraud. This study can be used as a guide for examiners in carrying out their responsibilities, especially in detecting fraud.

Keywords: Examination Experience; Red Flags; Audit Time Budget Pressure; Workload; Personality Type, Fraud.

Abstrak

Tindakan kecurangan yang sampai saat ini masih sering terjadi menunjukkan sulitnya menghapuskan tindakan tersebut. Kecurangan telah banyak merugikan ekonomi negara. Penelitian ini bertujuan untuk menganalisis pengaruh pengalaman pemeriksaan, red flags, tekanan anggaran waktu pemeriksaan, beban kerja, dan tipe kepribadian terhadap kemampuan pemeriksa dalam mendeteksi kecurangan. Penelitian ini menggunakan sampel jenuh atau sensus dengan jumlah populasi 32 pemeriksa independen Badan Pemeriksa Keuangan (BPK) Provinsi Kalimantan Timur. Data dikumpulkan melalui kuesioner online, dan dianalisis dengan menggunakan regresi linear berganda. Hasil penelitian ini menunjukkan bahwa pengalaman pemeriksaan dan red flags berpengaruh terhadap kemampuan mendeteksi kecurangan. Namun, variabel tekanan anggaran waktu pemeriksaan, skeptisisme profesional, beban kerja, dan tipe kepribadian tidak berpengaruh terhadap kemampuan mendeteksi kecurangan. Penelitian ini bisa menjadi referensi bagi pemeriksa dalam menjalankan tugasnya, terutama dalam mendeteksi kecurangan. Kata kunci: Pengalaman Pemeriksaan, Red Flags, Tekanan Anggaran Waktu Pemeriksaan, Beban Kerja, Kecurangan.
\end{abstract}

\section{PENDAHULUAN}

Kasus kecurangan yang menjadi topik berita di media masa setiap hari membuktikan bahwa terdapat kesulitan untuk menghapuskan dan bahkan mengurangi kecurangan. Pelaku kecurangan memiliki banyak cara untuk melakukan kecurangan dan bahkan perilaku kejahatan yang dilakukan semakin canggih. Hukum yang bersifat mengancam seperti tidak cukup menakutkan dan memberikan efek jera kepda para koruptor. Hal ini menjadi tugas dan tanggung jawab bagi seorang pemeriksa untuk lebih meningkatkan kemampuan dalam mendeteksi semua bentuk kecurangan. Fraud atau kecurangan adalah perbuatan tidak jujur yang dengan sengaja dilakukan untuk kepentingan pribadi atau kelompok yang berdampak pada kerugian di banyak pihak.

Berdasarkan Laporan Indeks Persepsi Korupsi (IPK) (2018), Indonesia menempati posisi ke89 dari 180 negara dengan nilai 38 dari skala 0-100. Hal ini lebih baik jika dibandingkan dengan tahun 2017 dimana Indonesia mendapatkan nilai 37 dan menempati urutan ke-96 (IPK, 2017). Adanya perbaikan peringkat ini belum bisa menjadikan penegak hukum dikatakan telah melakukan 
pemberantasan korupsi secara maksimal. Hasil pemantauan Indonesia Corruption Watch (ICW) tahun 2018 menunjukkan kerugian akibat perkara korupsi mencapai Rp9,29 triliiun (Rachman, 2019). Association of Certified Fraud Examiners (ACFE) Indonesia juga menekankan bahwa pada tahun 2016, fraud yang paling banyak terjadi di Indonesia ialah korupsi dengan 178 kasus, 41 kasus penyalahgunaan aktiva, dan 10 kasus kecurangan laporan keuangan (Murdock, 2018). Selain itu, Komisi Pemberantasan Korupsi (KPK) tahun 2018 telah melaporkan adanya 121 kasus korupsi dengan total barang bukti Rp24,4 miliar, USD14 ribu, dan SGD310 ribu. KPK juga menyita Rp 96,6 miliar total aset, 10 kendaraan roda empat, dan $27.293 \mathrm{~m}^{2}$ tanah dan bangunan yang dihibahkan ke kementerian atau lembaga (KPK, 2018).

Badan Pemeriksa Keuangan (BPK) ditunjuk oleh negara dan berperan sebagai agen negara yang bertugas untuk melakukan pemeriksaan. BPK merupakan lembaga yang bertugas untuk memeriksa seluruh entitas yang menggunakan uang negara. Berdasarkan Peraturan BPK Nomor 1 Tahun 2017 mengenai Standar Pemeriksaan Keuangan Negara (SPKN), nilai dasar organisasi BPK adalah independensi, integritas, dan profesionalisme. Dengan adanya BPK yang melaporkan setiap hasil pemeriksaan, pihak yang bertanggung jawab diharapkan dapat menjalankan tugas berdasarkan aturan dan standar yang berlaku. BPK yang berperan sebagai pemeriksa eksternal pemerintah harus kritis dan tanggap untuk mengungkap semua bentuk kecurangan. Masyarakat akan memperhatikan kinerja BPK sehingga pemeriksa BPK harus memiliki kemampuan yang baik untuk mendeteksi kecurangan dengan adanya bukti nyata dan kompeten.

Arsendy, Anugerah, \& Diyanto (2017) menyatakan bahwa seorang auditor akan mampu mendeteksi kecurangan dengan pengalaman audit yang dimiliki. Seorang auditor yang telah berpengalaman mempunyai lebih banyak hal yang dapat meningkatkan pengetahuan, keahlian, dan kemampuan dalam mendeteksi kecurangan dibandingkan dengan auditor yang kurang memiliki pengalaman. Dengan demikian, kemampuan auditor yang berpengalaman akan semakin baik dalam mendeteksi fraud (Arbaiti, Silfi, \& Ahzar, 2018). Dengan pengalaman audit, maka secara auditor otomatis telah terbiasa melakukan proses audit karena sudah sering melakukan pekerjaan yang sama. Dengan banyaknya pengalaman audit, auditor akan cepat mengetahui apabila terjadi kecurangan. Dengan demikian, dirumuskan hipotesis sebagai berikut:

$\mathrm{H}_{1}$ : Pengalaman pemeriksaan berpengaruh terhadap kemampuan pemeriksa dalam mendeteksi fraud.

Pemeriksa keuangan selain perlu memiliki pengalaman audit yang luas, juga dituntut untuk mampu memahami adanya gejala-gejala kecurangan (red flags) yang dapat mendukung pemeriksa dalam mendeteksi kecurangan. Red flags adalah segala hal yang tidak seperti biasanya sehingga memberikan petunjuk atau indikasi yang memungkinkan adanya tindakan kecurangan. Walaupun red flags tidak selalu menandakan adanya kecurangan, pengungkapan kecurangan sering ditandai dengan pengetahuan mengenai gejala red flags. Auditor yang memiliki pengetahuan tentang red flags akan lebih peka dalam mendeteksi adanya fraud (Arsendy, Anugerah, \& Diyanto, 2017). Dengan demikian, red flags dapat digunakan oleh auditor sebagai tanda atau peringatan awal yang memerlukan penyelidikan lebih lanjut kepada hal-hal yang mencurigakan. Hal ini dapat membantu langkah auditor selanjutnya untuk dapat memperoleh bukti-bukti yang diperlukan untuk mengungkap kecurangan (Amrizal, 2004). Sehubungan dengan pembahasan tersebut maka dirumuskan hipotesis sebagai berikut:

$\mathrm{H}_{2}$ : Red flags berpengaruh terhadap kemampuan pemeriksa dalam mendeteksi fraud.

Tekanan anggaran waktu merupakan pembatas waktu dan anggaran yang sangat ketat dan kaku yang ditujukan kepada auditor agar dapat melakukan efisiensi terhadap waktu yang diberikan (Pangestika, Taufik, \& Silfi, 2014). Penugasan yang diberikan kepada auditor harus diselesaikan sesuai tenggang waktu yang ditetapkan. Pemeriksa yang profesional mampu menyelesaikan pekerjaan secara efisien dan tepat waktu. Tekanan anggaran waktu pemeriksaan yang diberikan akan membuat auditor melakukan pemeriksaan tahap demi tahap sesuai dengan prosedur pemeriksaan yang telah dibuat, sehingga auditor mampu mendeteksi kecurangan (Arsendy, Anugerah, \& Diyanto, 2017). Dengan adanya tahapan-tahapan dalam melakukan audit, penugasan audit akan selesai tepat waktu sesuai prosedur yang ditetapkan. Namun, penelitian lain menyatakan bahwa semakin tinggi tekanan waktu yang diberikan kepada auditor untuk melakukan suatu pemeriksaan, maka semakin berkurang kemampuan auditor dalam melakukan pendeteksian kecurangan (Umri, Islahuddin, \& Nadirsyah, 2015). Oleh karena itu, dirumuskan:

$\mathrm{H}_{3}$ : Tekanan anggaran waktu pemeriksaan berpengaruh terhadap kemampuan pemeriksa dalam mendeteksi fraud. 
Sikap skeptisisme profesional merupakan keharusan yang dimiliki oleh pemeriksa, karena pemeriksa akan selalu mempertanyakan ketepatan dan bukti-bukti yang kompeten dalam setiap pemeriksaan. Dengan sikap skeptisisme profesional, auditor akan memiliki keinginan yang besar untuk mencari informasi tekait dengan gejala kecurangan (Umri, Islahuddin, \& Nadirsyah, 2015). Hal tersebut berarti pemeriksa tidak mudah percaya dengan segala sesuatu, tetapi bukan berarti pemeriksa tidak percaya kepada pihak yang bertanggung jawab. Pemeriksa dengan sikap skeptisisme profesional yang tinggi akan menunjang pemeriksa dalam mengungkapkan kecurangan (Larasati \& Pustipasari, 2019). Dengan skeptisisme profesional, pemeriksa dapat membuat penilaian kritis dengan pemikiran yang selalu mempertanyakan kecukupan dan ketepatan bukti yang diperlukan selama pemeriksaan (SPKN, 2017). Sehubungan dengan itu, dirumuskan hipotesis sebagai berikut:

$\mathrm{H}_{4}$ : Skeptisisme profesional berpengaruh terhadap kemampuan pemeriksa dalam mendetksi fraud.

Beban kerja yang timbul karena banyaknya penugasan pemeriksaan menjadikan pemeriksa merasa terbebani karena harus menyelesaikan seluruh tugas tersebut dalam batasan waktu yang telah diberikan sehingga dapat berpengaruh terhadap kualitas kinerja. Volume beban kerja yang tinggi tersebut akan menjadikan pemeriksa kelelahan dan kemudian bisa memengaruhi kemampuan dalam mendeteksi kecurangan (Molina \& Wulandari, 2018). Akan tetapi, pemeriksa yang berpengalaman tidak akan merasa terbebani dengan banyaknya penugasan yang diberikan. Hal tersebut disebabkan pemeriksa sudah mengalokasikan waktu yang diperlukan dalam pemeriksaan (Primasari, Mulyadi, \& Ahmar, 2019). Dengan adanya pengalaman melakukan pemeriksaan, pemeriksa sudah biasa dengan banyaknya tugas yang diberikan sehingga mampu menyelesaikan tugas dengan beban kerja yang banyak dalam tenggang waktu penugasan. Oleh karena itu, rumusan hipotesis adalah sebagai berikut:

$\mathrm{H}_{5}$ : Beban kerja berpengaruh terhadap kemampuan pemeriksa dalam mendeteksi fraud.

Faktor lain yang diduga memengaruhi kemampuan mendeteksi kecurangan adalah tipe kepribadian. Kepribadian adalah sesuatu yang membuat seorang berbeda dengan orang lain (Boeree, 2008). Tipe kepribadian bisa memengaruhi kemampuan auditor dalam mendeteksi kecurangan (Arbaiti, Silfi, \& Ahzar, 2018). Auditor dengan tipe kepribadian kombinasi Sensing-Thinking (ST) dan Intuition-Thinking (NT), dan auditor dengan tipe kepribadian lain tidak memiliki perbedaan dalam meningkatkan kemampuan pendeteksian kecurangan (Sari, Wirakusuma, \& Ratnadi, 2018). Kepribadian ST dan NT adalah tipe kepribadian yang gemar berfikir logis sehingga pemeriksa memiliki sikap skeptisisme yang tinggi. Sebaliknya, orang yang cenderung menggunakan perasaan tanpa berfikir logis dalam mempersiapkan sesuatu adalah orang dengan tipe kepribadian SensingFeeling (SF) dan Intuition-Feeling (NF). Dengan demikian diharapkan:

$\mathrm{H}_{6}$ : Tipe kepribadian berpengaruh terhadap kemampuan pemeriksa dalam mendeteksi fraud.

Kecurangan secara umum merupakan suatu tindakan yang melawan hukum dengan maksud untuk memperoleh keuntungan individu ataupun kelompok organisasi yang secara langsung merugikan pihak lain. Cara-cara melakukan kecurangan semakin canggih dan beragam seiring perkembangan zaman. Oleh sebab itu, dibutuhkan kesadaran dan pemahaman kemanusiaan serta hati nurani untuk tidak melakukan kecurangan, disamping kebutuhan adanya pemeriksa yang mahir, serta hukum yang ditakuti oleh pelaku kecurangan. Berdasarkan hal tersebut, tujuan penelitian ini adalah untuk melihat hubungan beberapa variabel yang diduga dapat memengaruhi kemampuan pemeriksa dalam mendeteksi kecurangan. Penelitian ini merupakan penelitian pengembangan dari penelitian sebelumnya (Arsendy, Anugerah, \& Diyanto, 2017), dengan menambahkan dua variabel yaitu beban kerja dan tipe kepribadian. Penelitian terdahulu menggunakan Kantor Akuntan Publik (KAP), sedangkan penelitian ini melibatkan BPK sebagai subyek penelitian. Penelitian menambah variabel beban kerja karena Kalimantan Timur memiliki 3 kota dan 7 kabupaten (103 kecamatan, 197 kelurahan, dan 841 desa), sedangkan jumlah seluruh pemeriksa BPK hanya 32 orang (Badan Pusat Statistik, 2019). Adanya perbedaan hasil penelitian terdahulu terkait tipe kepribadian menjadikan variabel tersebut kembali diteliti dalam penelitian ini.

\section{METODE}

Penelitian kuantitatif ini dilakukan dengan menggunakan analisis regresi linear berganda. Jumlah populasi adalah 32 orang pemeriksa di BPK RI di Kalimantan Timur. Dengan jumlah populasi yang kurang dari 100, maka penelitian ini menggunakan seluruh jumlah populasi menjadi responden. Metode yang digunakan adalah metode sampel jenuh dimana semua anggota populasi digunakan menjadi sampel (Sugiyono, 2018). Sumber data pada penelitian ini ialah data primer yang didapat 
melalui kuesioner. Persamaan analisis regresi linear berganda pada penelitian ini adalah sebagai berikut:

$$
Y=\beta_{0}+\beta_{1} X_{1}+\beta_{2} X_{2}+\beta_{3} X_{3}+\beta_{4} X_{4}+\beta_{5} X_{5}+\beta_{6} X_{6}+\varepsilon
$$

Variabel Y adalah kemampuan pemeriksa dalam mendeteksi fraud, $\beta$ adalah konstanta, $\beta$ hinga $\beta_{6}$ adalah koefisien regresi, $\mathrm{X}_{1}$ adalah pengalaman pemeriksaan, $\mathrm{X}_{2}$ adalah red flags, $\mathrm{X}_{3}$ adalah tekanan anggaran waktu pemeriksaan, $\mathrm{X}_{4}$ adalah septisisme profesional, $\mathrm{X}_{5}$ adalah beban kerja, $\mathrm{X}_{6}$ tipe kepribadian, dan $\varepsilon$ adalah eror.

\section{Kemampuan Pemeriksa dalam Mendeteksi fraud}

Kecurangan bisa terjadi dimanapun dan kapan saja, tetapi kecurangan mudah dihentikan atau bahkan dicegah. Kecurangan dapat merugikan banyak pihak terutama masyarakat yang sudah menyerahkan kepercayaan penuh kepada pemerintah untuk mengelola keuangan. Kecurangan (fraud) adalah perbuatan menghalalkan segala cara dengan tidak jujur seperti menipu, menyembunyikan, menggelapkan, atau menyalahgunakan kepercayaan demi keuntungan diri sendiri. Kecurangan bisa dalam bentuk uang, barang/jasa, dan tidak membayar jasa, yang dilakukan oleh satu individu atau lebih dari pihak yang bertanggung jawab atas tata kelola, pegawai, atau pihak ketiga (SPKN, 2017). Indikator yang digunakan dalam mendeteksi kecurangan adalah pemahaman terhadap struktur pengendalian internal entitas, kemampuan dalam menemukan faktor-faktor kecurangan, adanya sistem dan langkah-langkah yang terstruktur dalam pendeteksian kecurangan, dan pemahaman karakteristik-karakteristik kecurangan.

\section{Pengalaman Pemeriksaan}

Auditor yang sudah banyak mendapatkan penugasan pasti memiliki banyak pengalaman karena sudah menemui berbagai hal pada saat melakukan proses pemeriksaan. Semakin berpengalaman seorang auditor, maka auditor semakin banyak mengetahui hal-hal yang mungkin terjadi dalam memeriksa segala aspek yang diaudit (Arbaiti, Silfi, \& Ahzar, 2018). Dalam mempraktikan pertimbangan profesional, pemeriksa perlu memiliki pengetahuan dan pengalaman yang efektif dalam pemeriksaan, memahami standar dan ketentuan atas peraturan perundang-undangan, serta memahami operasional entitas yang diperiksa. Untuk membuat pertimbangan yang wajar, diperlukan pengalaman dan kompetensi. Indikator yang digunakan untuk variabel pengalaman pemeriksaan dalam penelitian ini yaitu banyaknya penugasan pemeriksaan.

\section{Red Flags}

Red flags merupakan tanda-tanda adanya sesuatu yang mencurigakan. Red flags sering ditandai dengan hal yang berbeda dari yang biasanya terjadi. Adanya sesuatu hal yang tidak biasa menjadikan seorang auditor memprediksi bahwa kecurangan mungkin telah terjadi. Prediksi adalah kesimpulan sementara yang berasal dari peristiwa atau keadaan pada saat itu yang dapat membawa akal sehat, profesional, dan kehati-hatian seseorang untuk meyakini sedang terjadi kecurangan atau akan terjadi kecurangan. Indikasi awal kecurangan adalah dengan mengetahui adanya sinyal red flags yang memberikan tanda kemungkinan terjadinya kecurangan (SPKN, 2017). Indikator yang digunakan untuk variabel red flags yaitu keagresifan suatu hal.

\section{Tekanan Anggaran Waktu Pemeriksaan}

Tekanan anggaran waktu pemeriksaan adalah batas waktu penugasan pemeriksa dalam melaksanakan pemeriksaan. Sebelum proses pemeriksaan dilaksanakan, pemeriksa harus mengetahui kewajiban dan sasaran yang dituju, serta berusaha agar proses audit dapat berjalan efisien dalam kurun waktu yang telah ditentukan. Auditor yang berpengalaman pasti akan memperkirakan waktu yang diperlukan untuk melaksanakan penugasan. Anggaran waktu penugasan yang diberikan tidak memengaruhi kemampuan auditor dalam mendeteksi kecurangan karena auditor sudah memperkirakan waktu yang dibutuhkan untuk menyelesaikan tugas audit (Dandi, Kamaliah, \& Safitri 2017). Supervisi diperlukan untuk menjaga agar kualitas laporan hasil akhir pemeriksaan sesuai dengan aturan, standar, dan prosedur penugasan dan dilakukan secara berjenjang. Untuk mencapai kualitas pemeriksaan sesuai dengan standar dan prosedur penugasan, supervisi perlu memprediksi kecukupan waktu yang diberikan untuk melaksanakan pekerjaan, meninjau kemampuan dan keahlian setiap tim pemeriksa, memahami atas instruksi yang diberikan, dan menyesuaikan pelaksanaan tugas 
dengan susunan yang telah direncanakan (SPKN, 2017). Indikator yang digunakan untuk variabel tekanan anggaran waktu pemeriksaan yaitu batasan waktu pemeriksaan.

\section{Skeptisisme Profesional}

Skeptis merupakan sifat seorang yang selalu ingin tau banyak hal, sedangkan profesional merupakan kepandaian khusus yang dimiliki untuk menjalankan sebuah profesi. Skeptisisme profesional berarti pemeriksa harus mempertanyakan lagi segala hal pada saat proses pemeriksaan kepada pihak yang bertanggung jawab pada laporan yang dibuat, tetapi bukan berarti pemeriksa menduga pihak yang bertanggung jawab tidak jujur. Pemeriksa menanggapi bahwa suatu kondisi tertentu dapat menimbulkan hal pokok yang tidak sesuai dengan kriteria yang seharusnya. Oleh karena itu, diperlukan perencanaan, pelaksanaan, dan pelaporan yang dilaksanakan oleh pemeriksa dengan sikap skeptisisme profesional. Dengan sikap skeptisisme profesional yang dimiliki, pemeriksa akan selalu mempertanyakan ketepatan dan kecukupan bukti selama proses pemeriksaan dan selalu melakukan penilaian kritis terhadap segala hal yang ditemukan pada proses pemeriksaan (SPKN, 2017). Indikator yang digunakan untuk variabel skeptisisme profesioanal yaitu kecukupan dan ketepatan bukti pemeriksaan

\section{Beban Kerja}

Jumlah penugasan yang dimiliki pemeriksa menambah beban kerja yang harus diselesaikan sesuai dengan jangka waktu yang ditetapkan. Faktor yang dapat memengaruhi kinerja di setiap organisasi adalah beban kerja yang diberikan. Untuk mencapai tujuan organisasi, diperlukan identifikasi beban kerja yang berhubungan dengan jumlah pekerja maupun jenis pekerja yang diperlukan. Langkah awal dalam perencanaan penugasan adalah menentukan strategi pemeriksaan secara keseluruhan dan mengembangkan rencana pemeriksaan. Informasi yang disampaikan dapat bermanfaat secara maksimal apabila laporan hasil pemeriksaan diserahkan tepat pada waktu yang ditentukan. Beban kerja tidak dapat digunakan sebagai alasan untuk mengurangi kemampuan seorang auditor dalam mendeteksi kecurangan dalam laporan keuangan, karena upaya untuk mendeteksi kecurangan merupakan tugas utama seorang auditor (Larasati \& Pustipasari, 2019). Kompetensi diperlukan untuk meyakinkan bahwa pemeriksa mempunyai keahlian yang sesuai dengan penugasan yang diberikan. Opini laporan keuangan merupakan tanggung jawab pemeriksa berdasarkan pemeriksaan yang sesuai dengan SPKN yang telah mengatur bahwa pemeriksa harus patuh terhadap kode etik dan membuat perencanaan serta pelaksanaan pemeriksaan agar memperoleh keyakinan yang memadai (SPKN, 2017). Indikator yang digunakan untuk variabel beban kerja yaitu waktu pemeriksaan, jumlah penugasan, dan tanggung jawab.

\section{Tipe Kepribadian}

Setiap orang memiliki kepribadian yang berbeda-beda. Orang yang berhati-hati lebih banyak belajar dibandingkan dengan orang yang tergesa-gesa, sehingga perilaku orang yang berhati-hati lebih sedikit berisiko. Pada penelitian ini, tipe kepribadian diukur dengan 40 indikator. Indikator ini memuat lima pernyataan tentang kepribadian extroversion, lima pernyataan yang menggambarkan kepribadian introversion, lima pernyataan kepribadian sensing, lima pernyataan kepribadian intuition, lima pernyataan yang menggambarkan thinking, lima pernyataan yang menggambarkan feeling, lima pernyataan tentang judging, dan lima pernyataan yang menggambarkan perceiving. Indikator yang digunakan untuk tipe kepribadian adalah tes Myers-Briggs Type Indicator (MBTI).

\section{Analisis Validitas dan Reliabilitas}

Ketepatan ukuran data dengan instrumen yang digunakan dapat diketahui dengan melakukan uji validitas. Data disebut valid apabila mengukur apa yang seharusnya diukur dan yang seharusnya dilakukan. Pernyataan tidak akan bermanfaat untuk penelitian apabila skalanya tidak valid. Kegiatan untuk mengkorelasikan skor butir-butir pernyataan kuesioner dengan skala total variabel merupakan uji validitas yang dilakukan dalam penelitian ini. Teknik yang digunakan adalah dengan menggunakan korelasi Pearson's product moment. Syarat nilai minimum koefisien korelasi agar suatu data dianggap valid adalah $\mathrm{r}>0,3$ (Sugiyono 2018).

Uji reliabilitas dimaksudkan untuk menguji sejauh mana hasil suatu pengukuran dapat dipercaya. Uji reliabilitas dilakukan dengan cara menggunakan nilai Cronbach's Alpha. Suatu instrumen dapat dikatakan handal jika koefesien Cronbach's Alpha lebih besar dari 0,6 (Pramesti, 2014). Hasil uji reliabilitas dengan metode Cronbach's Alpha digunakan pada instrumen untuk mengukur variabel pengalaman pemeriksaan, red flags, tekanan anggaran waktu pemeriksaan, beban kerja, dan tipe kepribadian. 


\section{Statistik Deskriptif}

Nilai rata-rata, median, maksimum, minimum, dan standar deviasi adalah bagian dari statistic deskriptif yang bisa membantu mendeskripsikan variabel-variabel pada penelitian ini. Hal tersebut digunakan untuk menggambarkan dan mendeskripsikan data yang telah terkumpul sebagaimana adanya tanpa bermaksud membuat kesimpulan yang berlaku untuk umum atau generalisasi (Sugiyono, 2018).

\section{Uji Normalitas}

Suatu penelitian yang baik memiliki data yang berdistribusi normal. Uji ini dimaksudkan untuk mengetahui apakah variabel dependen dan variabel independen dalam sebuah model regresi sudah berdistribusi normal atau tidak (Ghozali, 2018).

\section{Uji Multikolinearitas}

Kemiripan antara masing-masing variabel independen dalam satu model dapat ditemukan saat melakukan uji multikolinearitas. Menurut Ghozali (2018), "uji multikolinearitas bertujuan untuk menguji apakah model regresi ditemukan adanya kolerasi antara variabel bebas, model regresi yang baik seharusnya tidak terjadi kolerasi antara variabel independen". Jika ditemukan korelasi antara variabel independen maka dikatakan bahwa variabel itu tidak ortogonal. Variabel ortogonal adalah variabel bebas yang menilai korelasi antara sesama variabel bebas sama dengan nol.

\section{Uji Heteroskedastisitas}

Ghozali (2018) mengemukakan bahwa "uji heteroskedastisitas bertujuan untuk menguji apakah dalam model regresi terjadi ketidaksamaan varians dari residual satu pengamatan ke pengamatan yang lain". Heteroskedastisitas terjadi apabila varians dari residual satu pemantauan ke pemantauan yang lain berbeda. Namun, jika varians dari residual satu pemantauan ke pemantauan lain sama, maka disebut dengan homoskedastisitas. Model regresi yang baik adalah yang menunjukkan adanya homoskedastisitas atau tidak terjadi heteroskedastisitas.

\section{Uji Hipotesis}

Model analisis data pada penelitian ini ialah analisis regresi linear berganda yang digunakan untuk mengetahui pengaruh antara variabel dependen dan variabel independen. Model ini digunakan untuk mengetahui pengaruh variabel pengalaman pemeriksaan $\left(\mathrm{X}_{1}\right)$, red flags $\left(\mathrm{X}_{2}\right)$, tekanan anggaran waktu $\left(\mathrm{X}_{3}\right)$, skeptisme profesional $\left(\mathrm{X}_{4}\right)$, beban kerja $\left(\mathrm{X}_{5}\right)$, dan tipe kepribadian $\left(\mathrm{X}_{6}\right)$ terhadap kemampuan pemeriksa dalam mendeteksi fraud $(\mathrm{Y})$.

\section{HASIL DAN PEMBAHASAN}

Tabel 1 menunjukkan bahwa keseluruhan indikator yang mengukur variabel pengalaman pemeriksaan $\left(\mathrm{X}_{1}\right)$, red flags $\left(\mathrm{X}_{2}\right)$, skeptisisme profesional $\left(\mathrm{X}_{4}\right)$, tipe kepribadian $\left(\mathrm{X}_{6}\right)$, dan kemampuan pemeriksa dalam mendeteksi fraud $(\mathrm{Y})$ bernilai valid dengan nilai signifikansi kurang dari 0,05. Sehubungan dengan itu, tidak terdapat indikator yang dihapus untuk kelima variabel tersebut. Namun, terdapat satu indikator tekanan anggaran waktu $\left(\mathrm{X}_{3.13}\right)$ dan satu indikator beban kerja $\left(\mathrm{X}_{5.9}\right)$ yang tidak valid, sehingga kedua indikator tersebut tidak diikutsertakan dalam perhitungan selanjutnya.

Hasil uji reliabilitas instrumen pengalaman pemeriksaan, red flags, tekanan anggaran waktu pemeriksaan, skeptisisme profesional, beban kerja, tipe kepribadian, dan kemampuan pemeriksa dalam mendeteksi fraud disajikan dalam Tabel 2. Nilai Cronbach's Alpha variabel pengalaman pemeriksaan, red flags, tekanan anggaran waktu pemeriksaan, skeptisisme profesional, beban kerja, tipe kepribadian, dan kemampuan pemeriksa dalam mendeteksi fraud lebih besar dari 0,60 sehingga semua variabel dapat dikatakan reliabel.

\section{Karakteristik Responden}

Terdapat 32 responden yang dikelompokkan menjadi enam karakter berdasarkan jenis kelamin, usia, pendidikan, peran dalam tim, volume kegiatan pemeriksaan, serta pengalaman berpindah tugas. Sejumlah 23 responden (71,9\%) merupakan laki-laki dan 9 orang $(28,1 \%)$ adalah perempuan. Responden yang berusia 30 hingga 35 tahun adalah sebanyak 20 orang (62,5\%), usia 36 sampai 40 tahun sebanyak 9 orang $(28,1 \%)$, dan di atas 40 tahun sejumlah tiga orang $(9,4 \%)$. Responden yang memiliki pendidikan S1 sebanyak 20 orang (62,5\%) dan S2 sebanyak 12 orang (37,5\%). Berdasarkan 
Tabel 1. Uji Validitas

\begin{tabular}{|c|c|c|c|c|c|c|c|}
\hline \multirow[t]{2}{*}{ Varibel } & \multirow[t]{2}{*}{ Item } & \multicolumn{2}{|c|}{ Validitas } & \multirow[t]{2}{*}{ Varibel } & \multirow[t]{2}{*}{ Item } & \multicolumn{2}{|c|}{ Validitas } \\
\hline & & $\mathrm{R}$ & Keterangan & & & $\mathrm{R}$ & Keterangan \\
\hline \multirow{10}{*}{$\begin{array}{c}\text { Pengalaman } \\
\text { Pemeriksaan }\left(\mathrm{X}_{1}\right)\end{array}$} & $\mathrm{X} 1.1$ & 0,705 & Valid & \multirow[t]{10}{*}{ red flags $\left(\mathrm{X}_{2}\right)$} & $\mathrm{X} 2.1$ & 0,622 & Valid \\
\hline & $\mathrm{X} 1.2$ & 0,766 & Valid & & $\mathrm{X} 2.2$ & 0,727 & Valid \\
\hline & $\mathrm{X} 1.3$ & 0,862 & Valid & & $\mathrm{X} 2.3$ & 0,791 & Valid \\
\hline & $\mathrm{X} 1.4$ & 0,797 & Valid & & $\mathrm{X} 2.4$ & 0,794 & Valid \\
\hline & $\mathrm{X} 1.5$ & 0,835 & Valid & & $\mathrm{X} 2.5$ & 0,784 & Valid \\
\hline & $\mathrm{X} 1.6$ & 0,753 & Valid & & X2.6 & 0,876 & Valid \\
\hline & $\mathrm{X} 1.7$ & 0,899 & Valid & & $\mathrm{X} 2.7$ & 0,789 & Valid \\
\hline & $\mathrm{X} 1.8$ & 0,739 & Valid & & $\mathrm{X} 2.8$ & 0,803 & Valid \\
\hline & $\mathrm{X} 1.9$ & 0,851 & Valid & & X2.9 & 0,777 & Valid \\
\hline & $\mathrm{X} 1.10$ & 0,714 & Valid & & $\mathrm{X} 2.10$ & 0,766 & Valid \\
\hline \multirow{13}{*}{$\begin{array}{c}\text { Tekanan anggaran } \\
\text { waktu pemeriksaan } \\
\left(\mathrm{X}_{3}\right)\end{array}$} & X3.1 & 0,752 & Valid & \multirow{13}{*}{$\begin{array}{l}\text { Skeptisisme Pro- } \\
\text { fesional }\left(\mathrm{X}_{4}\right)\end{array}$} & $\mathrm{X} 4.1$ & 0,335 & Valid \\
\hline & X3.2 & 0,82 & Valid & & $\mathrm{X} 4.2$ & 0,535 & Valid \\
\hline & X3.3 & 0,881 & Valid & & $\mathrm{X} 4.3$ & 0,486 & Valid \\
\hline & X3.4 & 0,841 & Valid & & $\mathrm{X} 4.4$ & 0,699 & Valid \\
\hline & X3.5 & 0,858 & Valid & & $\mathrm{X} 4.5$ & 0,687 & Valid \\
\hline & X3.6 & 0,716 & Valid & & $\mathrm{X} 4.6$ & 0,710 & Valid \\
\hline & X3.7 & 0,834 & Valid & & $\mathrm{X} 4.7$ & 0,627 & Valid \\
\hline & X3.8 & 0,799 & Valid & & $\mathrm{X} 4.8$ & 0,705 & Valid \\
\hline & X3.9 & 0,672 & Valid & & $\mathrm{X} 4.9$ & 0,723 & Valid \\
\hline & X3.10 & 0,828 & Valid & & $\mathrm{X} 4.10$ & 0,559 & Valid \\
\hline & X3.11 & 0,671 & Valid & & & & \\
\hline & X3.12 & 0,82 & Valid & & & & \\
\hline & X3.13 & 0,248 & Gugur & & & & \\
\hline \multirow[t]{10}{*}{ Beban Kerja $\left(X_{5}\right)$} & $\mathrm{X} 5.1$ & 0,821 & Valid & \multirow{10}{*}{$\begin{array}{c}\text { Kemampuan } \\
\text { pemeriksa dalam } \\
\text { mendeteksi fraud } \\
\text { (Y) }\end{array}$} & Y.1 & 0,516 & Valid \\
\hline & $\mathrm{X} 5.2$ & 0,719 & Valid & & Y.2 & 0,567 & Valid \\
\hline & X5.3 & 0,823 & Valid & & Y.3 & 0,755 & Valid \\
\hline & X5.4 & 0,866 & Valid & & Y.4 & 0,849 & Valid \\
\hline & X5.5 & 0,596 & Valid & & Y.5 & 0,836 & Valid \\
\hline & $\mathrm{X} 5.6$ & 0,599 & Valid & & Y.6 & 0,713 & Valid \\
\hline & $\mathrm{X} 5.7$ & 0,638 & Valid & & Y.7 & 0,670 & Valid \\
\hline & X5.8 & 0,612 & Valid & & Y.8 & 0,787 & Valid \\
\hline & X5.9 & 0,273 & Gugur & & Y.9 & 0,742 & Valid \\
\hline & $\mathrm{X} 5.10$ & 0,508 & Valid & & Y.10 & 0,760 & Valid \\
\hline $\begin{array}{c}\text { Tipe Kepribadian } \\
\left(\mathrm{X}_{6}\right)\end{array}$ & $\mathrm{X} 6.1$ & 1,000 & Valid & & & & \\
\hline
\end{tabular}

peran dalam tim, terdapat 20 orang $(62,5 \%)$ sebagai anggota tim yunior, lima orang $(15,6 \%)$ sebagai ketua tim yunior, lima orang $(15,6 \%)$ sebagai anggota tim senior, satu orang yang merupakan ketua tim senior $(3,1 \%)$, dan satu orang sebagai pengendali teknis $(3,1 \%)$. Terdapat 10 orang responden $(31,3 \%)$ yang melakukan pemeriksaan lebih dari lima kali, sebanyak empat orang (12,5\%) melakukan pemeriksaan sebanyak 6 sampai $10 \mathrm{kali}$, sejumlah dua orang $(6,3 \%)$ telah memeriksa sebanyak 11 sampai 15 kali, sebanyak empat orang (12,5\%) melaksanakan pemeriksaan sebanyak 16-20 kali, dua orang $(6,3 \%)$ telah memeriksa sebanyak $21-25$ kali, dan 10 orang $(31,3 \%)$ telah melakukan pemeriksaan sebanyak di atas 25 kali. Mayoritas responden berpengalaman berpindah tugas ke satu tempat (19 
Tabel 2. Uji Reliabilitas

\begin{tabular}{lcc}
\hline \multicolumn{1}{c}{ Instrumen Variabel } & $\begin{array}{c}\text { Koefisien } \begin{array}{c}\text { Cron- } \\
\text { bach } \text { 's } \boldsymbol{A} \text { Ipha }\end{array} \\
\text { Pengalaman Pemeriksaan }\end{array}$ & Keterangan \\
Red Flgs & 0,927 & Reliabel \\
Tekanan Anggaran Waktu Pemeriksaan & 0,918 & Reliabel \\
Skeptisisme Profesional & 0,944 & Reliabel \\
Beban Kerja & 0,797 & Reliabel \\
Tipe Kepribadian & 0,861 & Reliabel \\
Kemampuan Pemeriksa dalam Mendeteksi fraud & 1,000 & Reliabel \\
\hline
\end{tabular}

Tabel 3. UJi Multikolinearitas

\begin{tabular}{lccl}
\hline \multicolumn{1}{c}{ Variabel Bebas } & Tolerance & VIF & Keterangan \\
\hline Pengalaman Pemeriksaan & 0,378 & 2,644 & Bebas Gejala Multikolinearitas \\
Red flags & 0,376 & 2,662 & Bebas Gejala Multikolinearitas \\
Tekanan Anggaran Waktu Pemeriksaan & 0,697 & 1,436 & Bebas Gejala Multikolinearitas \\
Skeptisisme Profesional & 0,449 & 2,226 & Bebas Gejala Multikolinearitas \\
Beban Kerja & 0,952 & 1,051 & Bebas Gejala Multikolinearitas \\
Tipe Kepribadian & 0,950 & 1,053 & Bebas Gejala Multikolinearitas \\
\hline
\end{tabular}

orang, 59,4\%), sedangkan yang pernah bertugas di dua sampai tiga tempat sebanyak tujuh orang $(21,9 \%)$, dan lebih dari tiga tempat sebanyak enam orang $(18,8 \%)$.

Uji asumsi klasik dilakukan sebelum analisa regresi. Pertama, yaitu pengecekan normalitas yang dilakukan dengan menggunakan uji Kolmogorov-Smirnov. Hasil uji menunjukkan nilai signifikansi sebesar 0,200 yang lebih besar dari 0,05. Hal tersebut mengindikasikan bahwa data penelitian memiliki distribusi normal. Kedua, berdasarkan hasil uji multikolinearitas di Tabel 3, diketahui bahwa nilai tolerance seluruh variabel bebas lebih besar dari 0,1 dan nilai Variance Inflation Factor (VIF) lebih kecil dari 10. Dengan demikian, model regresi dalam penelitian ini dapat dinyatakan terbebas dari gejala multikolinearitas (Ghozali, 2018).

\section{Hasil Analisis Regresi Berganda}

Berdasarkan data Tabel 4, dapat dibuat persamaan regresi linear berganda secara matematis adalah sebagai berikut:

$$
\begin{aligned}
& Y=\alpha+\beta_{1} X_{1}+\beta_{2} X_{2}+\beta_{3} X_{3}+\beta_{4} X_{4}+\beta_{5} X_{5}+\beta_{6} X_{6}+\varepsilon \\
& Y=3,920+0,455 X_{1}+0,299 X_{2}+0,045 X_{3}+0,128 X_{4}+-0,019 X_{5}+-1,301 X_{6}+\varepsilon
\end{aligned}
$$

Nilai koefisien determinasi sebesar 0,677 yang menunjukkan bahwa variasi dalam variabel kemampuan pemeriksa dalam mendeteksi fraud dijelaskan oleh enam variabel independen sebesar $67,7 \%$, sedangkan 32,3\% sisanya dijelaskan oleh variabel lain yang tidak diteliti pada penelitian ini.

\section{Pengalaman Pemeriksaan Berpengaruh terhadap Kemampuan Pemeriksa dalam Mendeteksi Fraud.}

Uji t untuk variabel pengalaman pemeriksaan menghasilkan nilai signifikansi sebesar 0,012 (Tabel 4), sehingga dapat disimpulkan bahwa variabel pengalaman pemeriksaan berpengaruh positif terhadap kemampuan pemeriksa dalam mendeteksi fraud. Sejumlah besar pengalaman pemeriksaan yang dimiliki menunjukkan semakin tingginya kemampuan pemeriksa dalam mendeteksi fraud sehingga akan memudahkan pemeriksa dalam menjalankan penugasan yang diberikan. Hasil ini mendukung hasil penelitian Arsendy, Anugerah, \& Diyanto, (2017) yang menyatakan bahwa pengalaman pemeriksaan berpengaruh terhadap kemampuan pemeriksa dalam mendeteksi fraud. Namun riset ini berbeda dengan riset yang dilakukan Larasati (2019) yang menyatakan bahwa 
Tabel 4. Hasil Pengujian Hipotesis

\begin{tabular}{|c|c|c|c|c|c|c|}
\hline Keterangan & $\begin{array}{c}\text { Koefisien } \\
\text { Regresi }(\beta)\end{array}$ & t-hitung & p-value & $\mathbf{R}$ & $\begin{array}{c}\mathbf{R} \\
\text { Square }\end{array}$ & $\begin{array}{l}\text { Adjusted } \\
\text { R Square }\end{array}$ \\
\hline Pengalaman Pemeriksaan $\mathrm{X}_{1}$ & 0,455 & 2,695 & 0,012 & & & \\
\hline Red flags $\mathrm{X}_{2}$ & 0,299 & 2,075 & 0,048 & & & \\
\hline $\begin{array}{c}\text { Tekanan Anggaran Waktu Pemeriksaan } \\
\mathrm{X}_{3}\end{array}$ & 0,045 & 0,762 & 0,453 & & & \\
\hline Skeptisisme Profesional $\mathrm{X}_{4}$ & 0,128 & 0,822 & 0,419 & & & \\
\hline Beban Kerja $X_{5}$ & $-0,019$ & $-0,218$ & 0,829 & & & \\
\hline \multirow[t]{2}{*}{ Tipe Kepribadian $\mathrm{X}_{6}$} & $-1,301$ & $-1,113$ & 0,268 & & & \\
\hline & & & & 0,860 & 0,390 & 0,677 \\
\hline
\end{tabular}

pengalaman seorang pemeriksa tidak berpengaruh terhadap kemampuan pemeriksa dalam mendeteksi fraud. Kondisi ini sesuai dengan teori agensi dimana hubungan antara pemeriksa dan negara adalah proses pendelegasikan negara kepada pemeriksa untuk melaksanakan proses pemeriksaan atas laporan keuangan yang dibuat oleh entitas. Dalam konteks ini, negara tentu menuntut hasil kinerja yang dilaporkan pemeriksa adalah yang tepat, jujur dan tanpa kesalahan. Hal ini dapat dilihat dari pemeriksa yang memiliki banyak pengalaman dalam melakukan pemeriksaan akan lebih baik dan akurat untuk dapat dan mengetahui serta mengungkap kecurangan yang terjadi.

\section{Red Flags Berpengaruh terhadap Kemampuan Pemeriksa dalam Mendeteksi Fraud.}

Tabel 4 menunjukkan bahwa red flags berpengaruh positif terhadap kemampuan pemeriksa dalam mendeteksi fraud. Banyaknya pengalaman yang dimiliki menjadikan pemeriksa terbiasa dengan proses dan alur pemeriksaan sehingga bisa dengan cepat mengetahui adanya gejala kecurangan. Hasil penelitian ini sejalan dengan peneltian yang dilakukan oleh Prasetyo (2015) yang menyatakan bahwa semakin tinggi tingkat red flags yang ditemukan pada saat penugasan, maka semakin tinggi kemampuan pemeriksa dalam mendeteksi fraud. Arsendy, Anugerah, \& Diyanto, (2017) juga menyatakan bahwa seorang pemeriksa yang memiliki pengetahuan red flags yang baik akan lebih peka dalam hal mendeteksi adanya kecurangan dibandingkan dengan pemeriksa yang kurang memiliki pengetahuan tentang red flags. Namun hasil penelitian ini berbeda dengan penelitian Hanifah (2017) yang menyatakan bahwa red flags tidak memengaruhi kemampuan mendeteksi fraud. Keterkaitan dengan teori agensi yakni pemeriksa sebagai agen mempunyai tanggung jawab untuk menyajikan informasi yang bermanfaat bagi pengguna informasi (masyarakat) sebagai principal. Hal ini berarti bahwa pemeriksa yang memiliki pengetahuan tentang red flags mampu mengungkap kecurangan yang terjadi. Kondisi tersebut menunjukkan informasi yang diterima masyarakat mempunyai kepastian, efesiensi, akuntabilitas, transparansi, serta kepastian nilai.

\section{Tekanan Anggaran Waktu tidak Berpengaruh terhadap Kemampuan Pemeriksa dalam Mendeteksi Fraud.}

Tekanan anggaran tidak memiliki hubungan yang signifikan dengan kemampuan pemeriksa dalam mendeteksi fraud (Tabel 4). Hasil penelitian ini sesuai dengan penelitian sebelumnya yang dilakukan oleh Pangestika, Taufik, \& Silfi (2014) yang menyatakan bahwa tidak adanya pengaruh ini dikarenakan cukupnya anggaran waktu pemeriksaan yang diberikan kepada pemeriksa. Namun, penelitian ini bertolak belakang dengan peneletian Arsendy, Anugerah, \& Diyanto, (2017) yang menyatakan bahwa tekanan anggaran waktu pemeriksaan berpengaruh terhadap kemampuan pemeriksa dalam mendeteksi fraud. Pemeriksa sebagai agen bertanggung jawab moral kepada pemerintah untuk melaporkan hasil pemeriksaan secara transparan. Sesuai peraturan, pemeriksa wajib mengomunikasikan seluruh hasil temuan dalam pemeriksaannya kepada semua pihak terkait, menghindari kesalahan atas hasil pemeriksaan, dan membuat laporan hasil pemeriksaan. Sebagai bentuk pertanggungjawaban itu, pemeriksa harus memiliki pengetahuan dan keahlian yang sesuai dengan penugasan yang diberikan, sehingga proses pemeriksaan dapat diselesaikan tepat waktu. 


\section{Skeptisisme Profesional tidak Berpengaruh terhadap Kemampuan Pemeriksa dalam Mendeteksi Fraud.}

Hasil penelitian sama dengan tekanan anggaran waktu, skeptisisme profesional juga tidak berpengaruh terhadap kemampuan pemeriksa dalam mendeteksi fraud. Hasil penelitian ini sejalan dengan penelitian yang dilakukan Ranu \& Merawati (2017) dan Sanjaya (2017) yang menyatakan bahwa sikap skeptisisme profesional tidak berpengaruh terhadap kemampuan pemeriksa dalam mendeteksi fraud. Hal ini dikarenakan pemeriksaan yang dijalankan sesuai dengan perencanaan strategi yang sebelumnya sudah disusun supervisi seperti tanggung jawab pemeriksa, topik pemeriksaan yang akan dilakukan, penetapan strategi pemeriksaan secara keseluruhan, dan pengembangan rencana pemeriksaan. Sikap skeptisisme profesional merupakan keharusan yang dimiliki pemeriksa. Dengan memilki pengetahuan tentang adanya gejala red flags, maka sikap skeptisisme profesional sudah termasuk ada dalam diri pemeriksa. Sikap skeptisisme profesional pemeriksa dicerminkan dengan selalu bersikap skeptis dan profesional selama proses pemeriksaan dan mengedepankan prinsip pertimbangan profesional (SPKN, 2017).

\section{Beban Kerja tidak Berpengaruh terhadap Kemampuan Pemeriksa dalam Mendeteksi Fraud.}

Penelitian ini juga menemukan bahwa beban kerja tidak berpengaruh terhadap kemampuan pemeriksa dalam mendeteksi fraud (Tabel 4). Hasil penelitian ini diperkuat dengan penelitian Primasari, Mulyadi, \& Ahmar (2019); Sari, Wirakusuma, \& Ratnadi (2018); dan Dandi, Kamaliah, \& Safitri (2017) yang menyatakan bahwa beban kerja tidak berpengaruh terhadap kemampuan pemeriksa dalam mendeteksi fraud. Beban kerja yang tinggi bukan suatu masalah karena pemeriksa sudah memiliki alokasi waktu yang disesuaikan dengan kompleksitas tugas yang diberikan, sehingga pemeriksa mampu melaksanakan tugas secara efisien, tanpa mengurangi kemampuan pemeriksa dalam mendeteksi fraud. Walaupun pemeriksa memiliki beban kerja yang banyak, pemeriksa dapat menyelesaikan seluruh pekerjaan sebelum batas waktu yang telah ditentukan dalam penugasan sebagai bentuk kewajiban moral. Pemeriksa sebagai representasi dari agen pada konteks teori agensi bertanggung jawab kepada pemerintah untuk melaporkan hasil pemeriksaan secara tepat waktu.

\section{Tipe Kepribadian tidak Berpengaruh terhadap Kemampuan Pemeriksa dalam Mendeteksi Fraud.}

Penelitian ini juga tidak dapat menemukan pengaruh antara tipe kepribadian terhadap kemampuan pemeriksa dalam mendeteksi fraud (Tabel 4). Hasil penelitian ini sejalan dengan peneliti sebelumnnya yang dilakukan oleh Sari, Wirakusuma, \& Ratnadi, (2018) yang menyatakan bahwa tipe kepribadian tidak berpengaruh terhadap kemampuan pemeriksa dalam mendeteksi fraud. Nasution \& Fitriany (2012) juga menyatakan bahwa pemeriksa dengan tipe kepribadian kombinasi ST dan NT dan pemeriksa dengan tipe kepribadian lainnya tidak memiliki perbedaan kemampuan mendeteksi fraud. Hal ini disebabkan karena adanya tipe kepribadian lain yang tidak dimasukkan dalam penelitian ini. Selain itu, pemeriksa dituntut untuk profesional dalam melakukan penugasan. Pemeriksa yang mampu mendeteksi fraud merupakan pemeriksa yang memiliki tipe kepribadian yang memiliki cara berfikir, berprasangka, dan bertindak baik dalam menemukan kecurangan. Untuk memastikan pemenuhan tanggung jawab kepada negara yang dalam teori agensi adalah principal serta masyarakat yang diwakili DPR sebagai agen, pemeriksa menetapkan standar pengendalian mutu dan selalu mengembangkan sistem pengendalian mutu pemeriksaan agar proses pemeriksaan yang dilakukan sesuai dengan standar pemeriksaan dan ketentuan perundang-undangan.

\section{SIMPULAN}

Hasil penelitian menunjukkan bahwa pengalaman pemeriksaan dan red flags berpengaruh terhadap kemampuan pemeriksa dalam mendeteksi fraud. Seorang pemeriksa yang berpengalaman akan semakin meningkatkan kemampuan dalam mendeteksi fraud. Begitu juga pemeriksa yang memiliki pengetahuan red flags. Namun, variabel tekanan anggaran waktu pemeriksaan, skeptisisme profesional, beban kerja dan tipe kepribadian tidak berpengaruh terhadap kemampuan pemeriksa dalam mendeteksi fraud. Studi ini menggunakan metode survei dimana tidak terdapat wawancara terkait dengan kuesioner yang diberikan sehingga memungkinkan terjadinya bias atas jawaban yang diberikan. Studi ini juga hanya menguji beberapa sikap yang harus dimiliki seorang pemeriksa dalam menjalankan tugasn. Penelitian ini juga terbatas dilakukan pada pemeriksa BPK RI perwakilan saja, sehingga belum bisa digeneralisasikan ke seluruh pemeriksa BPK RI. Hasil penelitian menunjukkan hal-hal yang perlu ada pada setiap diri pemeriksa guna menciptakan laporan hasil pemeriksaan yang 
sebenar-benarnya, bersih tanpa ada rekayasa ataupun kesalahan, dan mencegah atau meniadakan kecurangan. Hasil penelitian diharapkan ini dapat digunakan sebagai referensi untuk dapat mendeteksi fraud dengan baik.

\section{DAFTAR RUJUKAN}

Amrizal. (2004). Pencegahan dan Pendeteksian Kecurangan oleh Internal Auditor. Diklat BPKP, 117. http://bpkp.go.id/public/upload/unit/investigasi/files/Gambar/PDF/cegah_deteksi.pdf.

Arbaiti, Silfi, A., \& Ahzar, A. (2018). Pengaruh Pengalaman Auditor, Independensi, Skeptisme Profesional dan Tipe Kepribadian terhadap Kemampuan Auditor dalam Mendeteksi Kecurangan (Studi Empiris pada KAP di Wilayah Pekanbaru, Padang, dan Batam). Jurnal Online Mahasiswa Fakultas Ekonomi Universitas Riau, 1(1), 1-13.

Arsendy, M., Anugerah, R., \& Diyanto, V. (2017). Pengaruh Pengalaman Audit, Skeptisme Profesional, Red Flags, dan Tekanan Anggaran Waktu terhadap Kemampuan Auditor dalam Mendeteksi Kecurangan (Studi Empiris pada Kantor Akuntan Publik di DKI Jakarta). Jurnal Online Mahasiswa Fakultas Ekonomi Universitas Riau, 4(1), 1096-1107.

Badan Pemeriksa Keuangan. (2017). Standar Pemeriksaan Keuangan Negara Republik Indonesia Nomor 1 Tahun 2017.

Badan Pusat Statistik Provinsi Kalimantan Timur. (2019). Kalimantan Timur dalam Angka Tahun 2019. Samarinda : Badan Pusat Statistik.

Badan Pemeriksa Keuangan Republik Indonesia. (2019). Ikhtisar Hasil Pemeriksaan Semester I Tahun 2019, 1-426. https://www.bpk.go.id/ihps.

Badan Pengawas Keuangan dan Pembangunan. (2005). Keputusan Kepala Badan Pengawas Keuangan dan Pembangunan Nomor: KEP-971/K/SU/2005 tentang Pedoman Penyusunan Formasi Jabatan Fungsional Auditor di Lingkungan Aparat Pengawasan Internal Pemerintah. Jakarta.

Boeree, G. C. (2008). Personality Theories: Melacak Kepribadian Anda Bersama Psikologis Dunia. Yogjakarta: Primasophie.

Dandi, V., Kamaliah, \& Safitri, D. (2017). Pengaruh Beban Kerja, Pelatihan, dan Tekanan Waktu terhadap Kemampuan Auditor dalam Mendeteksi Kecurangan (Studi Empiris BPK RI Perwakilan Provinsi Riau). Jurnal Online Mahasiswa Fakultas Ekonomi Universitas Riau, 4(1), 911925.

Ghozali, I. (2018). Aplikasi Analisis Multivariate dengan Program IBM SPSS 25. Semarang: Badan Penerbit Universitas Diponegoro.

Indonesia Corruption Watch. (2018). Indonesia Corruption Watch Anual Report 2018. https://www. antikorupsi.org/id/article/laporan-akhir-tahun-icw-2018.

Indonesia Corruption Watch. (2018). Laporan Tren Penindakan Kasus Korupsi Tahun 2017. https:// antikorupsi.org/sites/default/files/dokumen/tren_korupsi_2017.pdf.

Indonesia Corruption Watch. (2018). Laporan Tren Penindakan Kasus Korupsi Tahun 2018. https:// antikorupsi.org/sites/default/files/laporan_tren_penindakan_kasus_korupsi_2018.pdf.

Komisi Pemberantasan Korupsi. (2018). Laporan Tahunan Komisi Pemberantasan Korupsi Tahun 2018. https://www.kpk.go.id/id/publikasi/laporan-tahunan/934-laporan-tahunan-kpk-2018.

Larasati, D., \& Puspitasari, W. (2019). Pengaruh Pengalaman, Independensi, Skeptisisme Profesional Auditor, Penerapan Etika, dan Beban Kerja terhadap Kemampuan Auditor dalam Mendeteksi Kecurangan. Jurnal Akuntansi Trisakti, 6(1), 31-42. doi: 10.25105/jat.v6i1.4845.

Molina \& Wulandari, S. (2018). Pengaruh Pengalaman, Beban Kerja, dan Tekanan Waktu terhadap Kemampuan Auditor dalam Mendeteksi Kecurangan. Jurnal Ilmu Akuntansi, 16(2), 43-55.

Mulyadi. (2010). Auditing. Jilid 1 (Edisi Kenam). Jakarta : Salemba Empat.

Murdock, H. (2018). Association of Certified Fraud Examiners (ACFE), Auditor Essential. doi: 10.1201/9781315178141-3.

Nasution, H., \& Fitriany. (2012). Pengaruh Beban Kerja, Pengalaman Audit, dan Tipe Kepribadian terhadap Skeptisme Profesional dan Kemampuan Auditor dalam Mendeteksi Kecurangan. Jurnal dan Prosiding Simposium Nasional Akuntansi, , 1-23. 
Okpianti, C. N. (2017). The Influence of Auditor's Experience, Ethic of Profession and Personality Toward Auditor's Profesional Skepticism and Auditor's Capability on Fraud Detection. 3(2), 5467.

Pangestika, W., Taufik, T., \&Silfi, A. (2014). Pengaruh Keahlian Profesional, Independensi, dan Tekanan Anggaran Waktu terhadap Pendeteksian Kecurangan. Jurnal Online Mahasiswa Fakultas Ekonomi Universitas Riau, 1(2), 1-15.

Pramesti, G. (2014). Kupas Tuntas Data Penelitian dengan SPSS 22. Jakarta: PT Elex Media Komputindo.

Prasetyo, S. (2015). Pengaruh Red Flags, Skeptisme Profesional Auditor, Kompetensi, Independensi, dan Profesionalisme terhadap Kemampuan Auditor dalam Mendeteksi Kecurangan (Studi Empiris ada Kantor Akuntan Publik). Jurnal Online Mahasiswa Fakultas Ekonomi Universitas Riau, $2(1), 1-15$.

Primasari, A., Mulyadi, J. M. V., \& Ahmar, N. (2019). Pengaruh Independensi, Audit Tenure, Beban Kerja, dan Tekanan Waktu terhadap Kemampuan Auditor dalam Mendeteksi Kecurangan dengan Variabel Moderasi Pemahaman Kondisi Entitas dan Supervisi. Jurnal Inovasi Manajemen Ekonomi dan Akuntansi, 1(1), 31-40.

Rachman, D. A. (2019). ICW: Kerugian Negara akibat Korupsi pada 2018 Capai Rp9,29 Triliun. https://nasional.kompas.com/read/2019/04/28/15294381/icw-kerugian-negara-akibat-korupsi- pada-2018capai-rp-929-triliun?page=all.

Ranu, G. A. Y. N., \& Merawati, L. K. (2017). Kemampuan Mendeteksi Fraud Berdasarkan Skeptisme Profesional, Beban Kerja, Pengalaman Audit, dan Tipe Kepribadian Auditor. Jurnal Riset Akuntansi, 7(1), 79-90.

Robbins, S. P., \& Judge, T. A. (2015). Perilaku Organisasi (R. Saraswati \& F. Sirait (Eds.); Edisi 16). Jakarta: Salemba Empat.

Sanjaya, A. (2019). Pengaruh Skeptisisme Profesional, Independensi, Kompetensi, Pelatihan Auditor, dan Resiko Audit terhadap Tanggung Jawab Auditor dalam Mendeteksi Kecurangan. Jurnal Akuntansi Bisnis, 15(1), 41-55. doi:10.24167/jab.v15i1.1350.

Sari, K. G. A., Wirakusuma, M. G., \& Ratnadi, N. M. D. (2018). Pengaruh Skeptisme Profesional, Etika, Tipe Kepribadian, Kompensasi, dan Pengalaman pada Pendeteksian Kecurangan. EJurnal Ekonomi dan Bisnis Universitas Udayana, 7(1), 29-56. doi:10.24843/EEB.2018.vo7.i01.p02.

Sugiyono. (2018). Metodologi Penelitian Kuantitatif, Kualitatif, dan R\&D. Bandung: Alfabeta.

Umri, C., Islahuddin, \& Nadirsyah. (2015). Pengaruh Sikap Skeptisisme Profesional Auditor, Bukti Audit Kompeten, dan Tekanan Waktu terhadap Pendeteksian Kecurangan. Jurnal Magister Akuntansi, 4(1), 20-28. 